\title{
JULY 1972
}

TWELFTH YEAR - No. 136
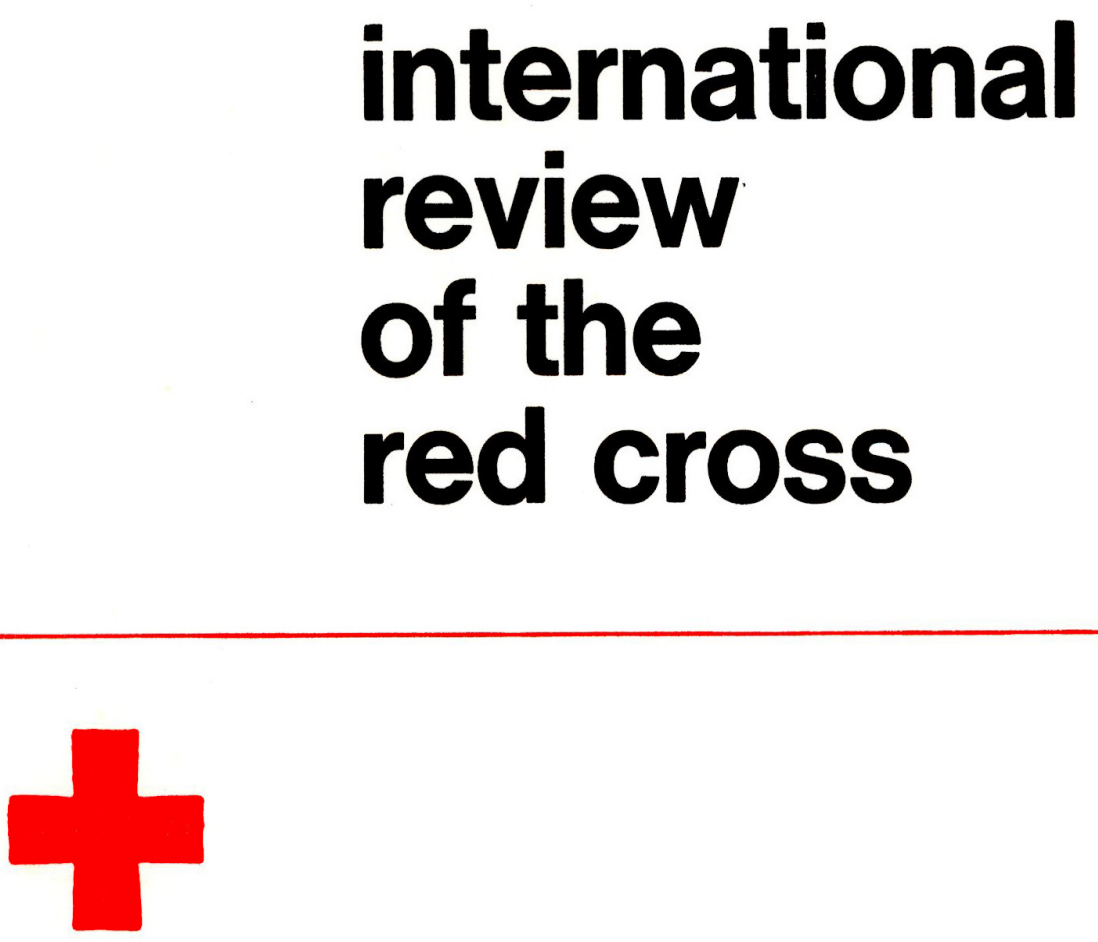

INTER ARMA CARITAS

\section{GENEVA}

INTERNATIONAL COMMITTEE OF THE RED CROSS FOUNDED IN 1863 


\section{INTERNATIONAL COMMITTEE OF THE RED CROSS}

MARCEL A. NAVILLE, President (member since 1967)

JEAN PICTET, Doctor of Laws, Chairman of the Legal Commission, Vice-President (1967)

HARALD HUBER, Doctor of Laws, Federal Court Judge, Vice-President (1969)

PAUL RUEGGER, Ambassador, President of the ICRC from 1948 to 1955 (1948)

GUILLAUME BORDIER, Certificated Engineer E.P.F., M.B.A. Harvard, Banker (1955)

HANS BACHMANN, Doctor of Laws, Winterthur Stadtrat (1958)

JACQUES FREYMOND, Doctor of Literature, Director of the Graduate Institute of International Studies, Professor at the University of Geneva (1959)

DIETRICH SCHINDLER, Doctor of Laws, Professor at the University of Zurich (1961)

MARJORIE DUVILLARD, Nurse (1961)

MAX PETITPIERRE, Doctor of Laws, former President of the Swiss Confederation (1961)

ADOLPHE GRAEDEL, member of the Swiss National Council from 1951 to 1963, former Secretary-General of the International Metal Workers Federation (1965)

DENISE BINDSCHEDLER-ROBERT, Doctor of Iaws, Professor at the Graduate Institute of International Studies (1967)

JACQUES F. DE ROUGEMONT, Doctor of Medicine (1967)

ROGER GALLOPIN, Doctor of Laws, former Director-General (1967)

WALDEMAR JUCKER, Doctor of Laws, Secretary, Union syndicale suisse (1967)

VICTOR H. UMBRICHT, Doctor of Laws, Managing Director (1970) on special leave

PIERRE MICHELI (1971)

Honorary members: Mr. JACQUES CHENEVIERE, Honorary Vice-President;

Miss LUCIE ODIER, Honorary Vice-President; Messrs. CARL J. BURCKHARDT, PAUL CARRY, Mrs. MARGUERITE GAUTIER-VAN BERCHEM, Messrs. SAMUEL A. GONARD, EDOUARD de HALLER, PAUL LOGOZ, RODOLFO OLGIATI, FREDERIC SIORDET, ALFREDO VANNOTTI, ADOLF VISCHER.

Directorate: Mr. JEAN-LOUIS LE FORT, Secretary-General.

Mr. CLAUDE PILLOUD, Director, Department of Principles and Law.

Mr. JEAN-PIERRE MAUNOIR, Assistant Director, Director of Operations ad interim. 


\section{INTERNATIONAL REVIEW OF THE RED CROSS}

JULY 1972 - No. 136

INTERNATIONAL COMMITTEE OF THE RED CROSS

IN THE RED CROSS WORLD

MISCELLANEOUS
José Daniel : The Vienna Convention of 1969 on the Law of Treaties and Humanitarian Law ....

Conference of Government Experts - Second

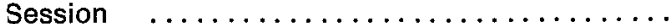

External Activities:

Asian sub-continent - Khmer Republic - Laos Philippines - Republic of Vietnam - Near East Burundi - Zaire - Paraguay - Uruguay - Venezuela - Northern Ireland ................ 391 In Geneva :

Presidential Council ................... 399

Participation in Geneva Conventions ....... 399

What is the role of an ICRC doctor-delegate ? .. 400

At the International Red Cross Museum ....... 402 Meeting of Red Cross Voluntary Workers ..... 403

Caritas Internationalis General Assembly ..... 404 World Health Assembly .................. 405 Some Aspects of Rehabilitation in Australia ... 406 The Pollution Problem .................. 411 
FRENCH EDITION

OF THE REVIEW

\section{SUPPLEMENTS}

TO THE REVIEW

\section{SPANISH}

GERMAN

\section{INTERNATIONAL}

REVIEW OF

THE RED CROSS
The French edition of this Review is issued every month under the title of Revue Internationale de la Croix-Rouge. It is, in principle, identical with the English edition and may be obtained under the same conditions.

Jacques Freymond: El Comité Internacional de la Cruz Roja en el sistema internacional (I) $-\dot{i}$ Cuál es el cometido de un delegado médico?

Jacques Freymond: Das Internationale Komitee vom Roten Kreuz im internationalen Gefüge (I).

The International Review is published each month by the International Committee of the Red Cross

7, avenue de la Paix, 1211 Geneva 1, Switzerland Postal Cheque No. 121767

Annual subscription: Sw. fr. $30 .-(\$ 8)$

Single copies Sw. fr. $3 .-(\$ 0.80)$

Editor: J.-G. LOSSIER

The International Committee of the Red Cross assumes responsibility only for material over its own signature. 